\title{
PENANAMAN DAN PENGOLAHAN TOGA (BUNGA ROSELA, DAUN INGSULIN, DAUN AFRIKA, DAUN BINAHONG, MAHKOTA DEWA, DAUN DEWA, BUNGA MENTEGA)
}

\author{
Sunu Catur Budiono ${ }^{1}$, Alam Setiyo Abadi $^{2}$, Anjas Irwanda ${ }^{3}$, dan Team KKN-PPM desa Gampang \\ ${ }^{1,2,3}$ Fakultas Keguruan dan Ilmu Pendidikan, Universitas PGRI Adi Buana Surabaya \\ Email: ${ }^{2}$ alamsetiyo@gmail.com, ${ }^{3}$ anjasindo1895@gmail.com
}

\begin{abstract}
Related to the health of rural communities a wide range of medicines here TOGA program implemented because the plant needed an alternative treatment that can be done independently to create an environment and a healthy society. TOGA is the cultivation of plants that have medicinal properties housing. Parks family medicine is essentially a piece of land either in the yard, garden, or fields used to cultivate plants that have medicinal properties in order to meet family needs will be drugs. In addition to planting program will be completed subsequent processing of TOGA investment process with a wide range of processing results. Hopefully the use of TOGA able to create a society that is able to maintain good health with traditionally.
\end{abstract}

Keyword : Plant TOGA, Significan TOGA, Making TOGA

\begin{abstract}
ABSTRAK
Berkaitan dengan kesehatan masyarakat pedesaan berbagai macam obat-obatan disini program tanaman TOGA dilaksanakan karena diperlukan adanya alternatif pengobatan yang dapat dilakukan secara mandiri untuk dapat menciptakan lingkungan dan masyarakat yang sehat. TOGA adalah tanaman hasil budidaya rumahan yang berkhasiat sebagai obat. Taman obat keluarga pada hakekatnya adalah sebidang tanah baik di halaman rumah, kebun, ataupun ladang yang digunakan untuk membudidayakan tanaman yang berkhasiat sebagai obat dalam rangka memenuhi keperluan keluarga akan obat-obatan. Selain program penanaman selesai dilakukan selanjutnya akan dilakukan pengolahan dari proses penanaman TOGA dengan berbagai macam hasil pengolahan. Semoga dari pemanfaatan TOGA mampu menciptakan masyarakat yang mampu memelihara kesehatan dengan secara tradisonal.
\end{abstract}

Kata kunci :Tanaman TOGA, Manfaat TOGA, Pengolahan TOGA

\section{PENDAHULUAN}

Program tanaman TOGA dilaksanakan karena diperlukan adanya alternatif pengobatan yang dapat dilakukan secara mandiri untuk dapat menciptakan lingkungan dan masyarakat yang sehat. TOGA adalah tanaman hasil budidaya rumahan yang berkhasiat sebagai obat. Taman obat keluarga pada hakekatnya adalah sebidang tanah baik di halaman rumah, kebun, ataupun ladang yang digunakan untuk membudidayakan tanaman yang berkhasiat sebagai obat dalam rangka memenuhi keperluan keluarga akan obat-obatan. Selain program penanaman selesai dilakukan selanjutnya akan dilakukan pengolahan dari proses penanaman TOGA dengan berbagai macam hasil pengolahan.

Budidaya tanaman obat keluarga dapat memacu usaha kecil dan menengah di bidang obat-obatan herbal sekalipun dilakukan secara individual. Setiap keluarga dapat membudidayakan tanaman obat secara mandiri dan memanfaatkannya sehingga akan terwujud prinsip kemandirian dalam pengobatan keluarga.

Oleh karena itu, kami sebagai mahasiswa KKN Universitas PGRI Adi Buana Surabaya ingin menyelenggarakan program yaitu "Penanaman dan Cara Mengolah Tanaman Obat Keluarga sebagai Alternatif Pengobatan Dengan Memanfaatkan Potensi Lokal" sebagai langkah awal untuk menanamkan jiwa yang mandiri serta peduli akan kesehatan pada masyarakat Desa Gampang Kecamatan Prambon Kabupaten Sidoarjo.

Berikut 


\section{METODE PENELITIAN}

Sosialisasi ini dilaksanakan pada tanggal 2 februari 2017, tempat sosialisasi di balai desa Gampang Kecamatan Prambon Kabupaten Sidoarjo dengan pengambilan data angket. Subjek dalam sosialisasi ini adalah masyarakat desa Gampang yang terdiri dari 60 orang. Penyebaran angket dilakukan setelah sosialisasi. Dalam penyebaran angket ini diambil 11 sampel dari 60 orang yang hadir dalam acara sosialisasi. Subjek sampel yang telah terpilih kemudian diberikan angket untuk mengetahui manfaat TOGA (Tanaman Obat Kelauarga ) bagi kesehatan dan juga sebagai obat herbal kesehatan obat herbal tingkat

- Panci

- Kompor

- Sudip/sutil

- LPG

- Blender

- Gula 2kg

b. Bahan

- Daun/batang Insulin

- Tanaman Rosella

- Pupuk Kandang

- Binahong

- Daun Dewa

- Bunga Mentega

- Mahkota Dewa

\section{HASIL PENELITIAN PEMBAHASAN}

Sosialisasi dan proses pengumpulan data yang dilakukan di balai desa Gampang Kecamatan Prambon Kabupaten Sidoarjo, jumlah masyarakat yang hadir dalam sosialisasi "penanaman dan pengolahan tanaman obat keluarga (TOGA) di desa Gampang, kecamatan Prambon, kabupaten Sidoarjo" adalah 60 Orang. Pada tanggal 2 februari 2017 dilakukan sosialisasi dan penyebaran angket. Dan angket yang sudah diisi dikembalikan selanjutnya dihitung nilai-nilai angket TOGA ditabulasikan dengan memberikan bobot kepada masingmasing alternatif jawaban. Instrumen penelitian yang digunakan adalah angket berupa 10 pertanyaan yang sudah disediakan jawaban untuk responden.

Tabel

PenilaianAngket

\begin{tabular}{|c|c|c|c|c|}
\hline Alternatif & SS & S & RR & TS \\
\hline Nilai / Skor & 4 & 3 & 2 & 1 \\
\hline
\end{tabular}

kesadaran masyarakat akan bahaya BAB (Buang Air Besar Sembarangan) di desa Gampang Kecamatan Prambon.

Instrument utama dalam penelitian ini adalah sosialisasi, penanaman, dan pengolahan TOGA sedangkan instrument pendukung adalah angket. Angket untuk mengetahui manfaaat TOGA sebagai obat herbal tradisional. Untuk kegiatanya memerlukan beberapa alat dan bahan, meliputi.

a. alat

$$
\begin{array}{ll}
\text { - } & \text { Cangkul } \\
\text { - } & \text { Timba } \\
\text { - } & \text { Cetok }
\end{array}
$$

\section{Pembahasan}

Setelah data diperoleh dari angket kemudian dihitung dengan menggunakan rumus :

$$
\frac{F}{N} \times 100 \%
$$

Keterangan:

$F=$ hasil perhitungan angket individu

$N=$ nilai tertinggi

Setelah

$\mathrm{t}_{\text {hitungdiperolehmakauntukmengetahuikriteria }}$ dalam angket sebagai berikut:

\begin{tabular}{|c|c|}
\hline Interval Koefisien & $\begin{array}{c}\text { Tingkat } \\
\text { Pemahaman }\end{array}$ \\
\hline $1 \%-25 \%$ & Kurang paham \\
\hline $26 \%-50 \%$ & Cukup paham \\
\hline $51 \%-75 \%$ & Paham \\
\hline $76 \%-100 \%$ & Sangat paham \\
\hline
\end{tabular}

Dari proses perhitungandidapatkan ratarata yaitu $86,13 \%$ yang menyatakan bahwa responden sangat paham, hal ini dapat dilihat dari interval koefisien. Dengan demikian dari hasil sosialisasi TOGA (Tanaman Obat Keluarga) dapatdiinterprestasikanbahwa masyarakat paham mengenai arti pentingnya obat herbal. Dengan adanya sosialisasi mengenai TOGA diharapkan masyarakat Desa Gampang Kecamatan Prambon menjadi lebih paham dan mengerti bahwa obat herbal jauh lebih baik dan mempunyai berbagai macam manfaat.

\section{SIMPULAN DAN SARAN}

Simpulan

Berdasarkan sosialisasi penaanaman dan pengolahan TOGA dapat disimpulkan bahwa 
masyarakat sangat paham betapa pentingnya obat herbal dalam kesehatan masyakarat pedesaan.

Saran

Berdasarkan simpulan dalam sosialisasi ini maka penulis memberikan saran yang berkaitan dengan sosialisasi. Saran yang diberikan penulis dalam hal ini adalah "diharapkan masyarakat Gampang mampu mengolah tanaman herbal sebagai obatn kesehatan yang alami."

\section{DAFTAR PUSTAKA}

http://simlitabmas.dikti.go.id/fileUpload/pengu muman/Panduan-Artikel-Hibah-PPM.pdf http://docplayer.info/340881-Kumpulanartikel-kegiatan-pengabdian-kepadamasyarakat.htmlhttp://blogku8994.blogspot.co. id/2014/08/proposal-pembuatan-rumahtoga.html http://caramencegah.com/search/contoh+propo sal+tanaman+obat+keluarga https://www.scribd.com/doc/189149598/Propo sal-TOGA

https://id.wikipedia.org/wiki/Tanaman_obat_ke luarga http://lemlit.undiksha.ac.id/media/1387.pdf http://p2m.polibatam.ac.id/wpcontent/uploads/2011/12/Panduan-PenulisanArtikel-Program-Pengabdian-kepadaMasyarakat.pdf 
